\title{
Tel Erozyon Yöntemiyle İşlenmiş Ti 6Al 4V Alaşımının Yüzey Kalitesinin Manyetik Aşındırıcılarla İşleme Yöntemiyle İyileştirilmesi
}

\author{
Mahmut ÇELİK ${ }^{*}$, Hakan GÜRÜN², Ulaş ÇAYDAŞ ${ }^{3}$ \\ ${ }^{1}$ Uçak Gönde ve Motor Bakımı Bölümü, Havacılık ve Uzay Bilimleri Fakültesi, Erciyes Üniversitesi, Kayseri, Türkiye \\ ${ }^{2}$ İmalat Mühendisliği Bölümü, Teknoloji Fakültesi, Gazi Üniversitesi, Ankara, Türkiye \\ ${ }^{3}$ Makine Mühendisliği Bölümü, Teknoloji Fakültesi, Fırat Üniversitesi, Elazığ, Türkiye \\ ${ }^{* 1}$ mahmutcelik@erciyes.edu.tr, ${ }^{2}$ hgurun@ gazi.edu.tr, ${ }^{3}$ ucaydas@ firat.edu.tr
}

Öz: Tel erozyonla işleme (TEİ) yöntemi işlenmesi zor malzemeler grubunda yer alan Ti 6Al 4V alaşımının işlenmesinde kullanılan geleneksel olmayan bir imalat yöntemidir. Yöntemde işlenen malzeme yüzeyinde, çatlaklar, yeniden katılaşmış artık tabakalar ve kraterler gibi malzemenin mekanik özelliklerini etkileyen istenmeyen oluşumlar meydana gelmektedir. Bu oluşumların ortadan kaldırılarak hem mekanik özelliklerinin hem de yüzey kalitesinin iyileştirilmesi için ikinci bir bitirme işlemine ihtiyaç duyulmaktadır. Bu çalışmada tel erozyon yöntemiyle sabit işleme koşullarında işlenmiş olan Ti $6 \mathrm{Al} 4 \mathrm{~V}$ alaşımından imal edilmiş olan numunelerin yüzey kaliteleri manyetik aşındırıcılarla işleme yöntemiyle artırılmıştır. Çalışmada, işleme süresi, aşındırıcı boyutu, devir sayısı ve manyetik alan miktarı parametrelerinin işlem performansı üzerindeki etkileri Taguchi L9 ortogonal dizin deneysel tasarımıyla incelenmiştir. Manyetik aşındırıcılarla işleme işlemi sonrası yüzey pürüzlülüğündeki iyileşme oranları (YPİO) ve talaş kaldırma oranları (TKO) belirlenmiştir. Numunelere ait taramalı elektron mikroskobu (SEM) görüntüleri alınmış ve yüzey özellikleri ve artık tabaka yapıları incelenmiştir. Çalışma sonucunda TKO değerlerinin işleme süresinin artmasıyla azalırken, aşındırıcı boyutu, devir sayısı ve manyetik alan miktarının artmasıyla arttığı, YPİO değerlerinin ise ortalama \%92 olarak ölçüldü̆ğu ve uygun işleme koşullarıyla bu sonucun \%96 oranlarına kadar arttığı tespit edilmiştir. Artık tabaka miktarının ise yapılan bütün deneylerde tamamen ortadan kaldırıldığı tespit edilmiştir.

Anahtar kelimeler: Manyetik aşındırıcılarla işleme, Tel erozyonla işleme, Yüzey kalitesi, Artık tabaka, Ti-6Al-4V

\section{Improvement of Surface Quality of W-EDMed Ti 6Al 4V Alloy by Magnetic Abrasive Finishing}

\begin{abstract}
Wire electro discharge machining method is an unconventional manufacturing method used in the machining of Ti $6 \mathrm{Al} 4 \mathrm{~V}$ alloy, which is in the group of materials that are difficult to machine. Undesirable formations such as cracks, recast layers and craters that affect the mechanical properties of the material occur on the surface of the material machined in the method. A second finishing process is required to eliminate these formations and improve both the mechanical properties and the surface quality. In this study, the surface qualities of the specimens made of $\mathrm{Ti} 6 \mathrm{Al} 4 \mathrm{~V}$ alloy machined with wire electro discharge method under constant machining conditions were increased by magnetic abrasive finishing method. In the study, the effects of machining time, abrasive size, number of cycles and magnetic field parameters on process performance were investigated with the experimental design of Taguchi L9 orthogonal array. After machining with magnetic abrasives, surface roughness improvement rates (SRIR) and material removal rates (MRR) were determined. Scanning electron microscopy (SEM) images of the specimens were taken and surface properties and recast layer structures were examined. As a result of the study, it was determined that the MRR values decreased with the increase of the processing time; increase with the increase of abrasive size, the rotation number and the magnetic field, SRIR values were measured as $92 \%$ on average and this result increased up to $96 \%$ with appropriate processing conditions. It has been determined that the amount of residual layer has been completely removed in all experiments.
\end{abstract}

Key words: Magnetic abrasive finishing, Wire electro discharge machining, Surface quality, Recast layer, Ti-6Al$4 \mathrm{~V}$.

\section{Giriş}

Mühendislik uygulamalarında kullanılan bir ürüne ham maddeden nihai ürün oluşumuna kadar geçen süreçte genellikle, döküm, plastik şekil verme, talaşlı imalat ve gerekli olması halinde ısıl işlem basamakları uygulanmaktadır. Bu süreçler sonrasında oluşan ürünlerde farklı seviyelerde yüzey pürüzlülüğü ve kılcal çatlaklar,.

\footnotetext{
${ }^{*}$ Sorumlu yazar: mahmutcelik@erciyes.edu.tr. Yazarların ORCID Numarası: ${ }^{1} 0000-0003-4272-1319,{ }^{2}$ 0000-0001-6189-6830, ${ }^{3} 0000-$ 0001-6706-1332
} 